\title{
The Role of Individual Cultural Values in Personal Innovativeness
}

\author{
N.D.N.B. Rathnayake \\ Faculty of Management and Finance \\ University of Colombo \\ Colombo \\ SRI LANKA \\ nishamani.rathnayake@gmail.com
}

\begin{abstract}
According to the Innovation Diffusion Theory, personal innovativeness is a key component to an individual's decision-making process. Theoretically, however, it does not very clearly describe the role of cultural values in personal innovativeness. If culture influences individuals' traits, it is necessary to discuss in depth about this relationship, as personal innovativeness a trait. This article, therefore, justifies the importance of further discussing the contribution of cultural values to personal innovativeness using the theory of innovation diffusion. A systematic literature review was conducted for this qualitative analysis, and relevant theories and models were identified to elaborate on the key precursors and concerns identified with existing knowledge. A conceptual map was developed with existing knowledge that expands the knowledge gap for current research.
\end{abstract}

Keywords:- Personal Innovativeness, Individual Cultural Values, Innovation Decision Process, Innovation Diffusion Theory.

\section{INTRODUCTION}

Personal Innovativeness (PI) is defined as a key priority that affects a person when deciding to adopt any new product or service. Depending on how long it takes a person to use a product or service, he or she can be classified into PI levels. The rapport between PI and a persons' decision process is discussed in depth in Rogers' (1971) Innovation Diffusion
Theory (IDT). Research also identifies PI as a personality trait. According to trait theories, culture influences every trait. Therefore, when it comes to PI, it is clear that it has a cultural influence because it is a trait. Thus, this article does not attempt to measure the relationship between culture and PI. Instead, the focus of this article is to delve deeper into how culture partakes on PI, in what way, and what is the role of culture on PI and the 
decision process. Because culture is a broad area, this study is focused on cultural values identified as an implication of culture. Hence, the focus is on cultural values to further narrow the study theme. In fact, it may be broad and not practical to consider all those cultural values, as there are many cultural values discussed in the literature.

It is therefore based on four cultural values (Individualism/ collectivis, Power distance, Uncertainty avoidance and Masculinity/femininity) that are widely discussed in the literature and have strong theoretical basis (Kluckhohn \& Stordtbeck, 1961; Schwartz, 1999; Smith, Dugan \& Trompenaars,1996; Triandis, 2001; Hui \& Triandis, 1986; Markus \& Kitayama,1991; Hofstede \& Bond, 1984; Hooi, 2007; Mooij \& Hofstede, 2011; Mooij \& Hofstede, 2010; Hofstede, 1983; Wu,2006; Orr \& Hauser,2008; Hofstede, 2011; Carl, Gupta \& Javindan, 2004; Daniels \& Greguras, 2014; Luque \& Javindan, 2004; Emrich, Denmark \& Hartog,2004). This is because there is a dearth of studies in understanding these four values (as individual values) through PI. For future studies, one can study how other cultural values and cultural implications contribute to PI. This is because PI is not just a persons' motivational stimulus $(\mathrm{Lu}$ et al.,2005). There, any innovation that is not accepted by its' prospective user will not benefit the seller.
Therefore, understanding PI in various domains will help innovators to identify the exact needs of the market, and to pitch it with their innovative ideas ( $\mathrm{Lu}$ et al.,2005). In addition, a person's PI determines when and how to adopt. Therefore, when promoting a product, marketers must have a deep understanding of people's PIs, in determining the target audience for their product promotion campaigns (Lu et al.,2005; Lu, 2014). Therefore, understanding the role of ICV in PI will broaden the overall knowledge of PI from a cultural perspective.

\section{THEORETICAL BACKGROUND}

\subsection{Personal innovativeness and technology adoption:}

When it comes to adopting new products/services, technology adoption takes precedence. That is because innovativeness (IN) is often intertwined with technology. The two popular theories that discuss technology adoption are the Technology Acceptance Model (TAM) and the Unified Theory of Acceptance and Use of Technology (UTAUT). As it is most explained, TAM primarily focuses on Usefulness and Ease of Use; two separate beliefs and their influence on attitude and behaviour. There are different TAM model versions, though none of the new versions considers PI as a variable in their models (Lu et al.,2005; Agarwal 
\& Prasad, 1998). Also, in UTAUT, variables such as performance expectancy, effort expectancy, social influence, and facilitating conditions have been considered as the main determinants of behavioural intention/behaviour, and there are four moderating variables such as gender, age, experience, and voluntariness use. However, it was observed that, UTAUT also did not consider PI in their original model (Venkatesh et al., 2003; Xu \& Gupta, 2009).

Accordingly, attention was drawn to IDT as none of the above theories discussed the concept of PI. Accordingly, regarding the individual IN categories, the IDT is very clearly described. It explains that the individuals separated into adopter categories are based on their level of PI.

Thus, IDT elaborates PI as a prior condition for the consumer's decision process. There, the consumer's decision process was referred to as the process of innovation decision. It explains that the Innovation Decision Process (IDP) has five stages and persons' IN is considered as a prior condition for that. There, it explains a persons' level of IN as a degree that an individual adopts a new idea relatively earlier than the other members of the system (Rogers, 1971). Practically, Innovation is not always easy to adopt, because it can be complex and expensive to implement (Aboagye, 2016). For these reasons, people use innovations at different times. Accordingly, a person's level of IN can be classified into segments as; innovators, early adopters, early majority, late majority, and laggards (Rogers, 1971).

Several research papers have studied PI at different levels. For example, Lu et al. (2005) explained that PI has a strong relationship with perceived usefulness and perceived ease of use. Also, Midgley and Dowling (1978) have proposed a model to explain how psychological and sociological traits are associated with IN. He argues that not to consider "time of adopting" a product and PI being similar concepts, since IN always depends on factors like communications and favourable /unfavourable situations.

However, according to Rogers' (1971) IDP, communication influences the consumer's decision making when adopting an innovative product. PI is a prior condition in the IDP and the time of adopting the product is taken as the measurement for the outcome of PI.

Discussing further about IN, Bigné-Alcañiz et al. (2008) describe the IN of a person to be explained as general or productspecific. General IN discusses the openness to new experiences and being a predictor of shopping intention. Product-specific IN has been associated with a specific product or service rather than 
with a generic characteristic of an individual's personality.

The above discussion was about the definition given to PI by various researchers. Looking further, researchers have considered PI as a trait and a symbol of risk-taking propensity (Lu et al., 2005; Agarwal \& Prasad, 1998; Midgley \& Dowling, 1978; Rogers, 1971).

When discussing trait in technology adoption, in 2009, Jacques and the team presented a modified TAM model to test how the big five- personality factor model(Extraversion,Agreeableness, Conscientiousnes, Neuroticism, Openness) of personality traits (McCrae \& Costa,1997) lead to the intention of using Virtual Reality Systems (VRT). However, that discussion does not talks about PI.

Considering all the facts looking from the perspective of a trait, PI may originate as a reason for a person's characteristics and cultural influences. It might not be right to argue that PI is directly dependent on the communication or situation, but the customer's decision process may do. Therefore, PI and the decision-making process are not the same (Midgley \& Dowling, 1978).

Accordingly, although there are many models to explain the process of technology adoption, to the best knowledge of the author, it is required to explore more on PI (as a trait) to understand the propensity of an individual's technology adoption (Agarwal \& Prasad, 1998; Lu et al.,2005). In that sense, the most appropriate theory for further discussion of PI is IDT.

\subsection{Traits and Culture}

Traits are scientific constructs related to human behaviour; and defined as dimensions of individual differences to show consistent patterns of thoughts, feelings, and actions (Costa \& McCrae, 1998; Johnson, 1997). Theoretically, traits do not only base on biological phenomena, but the characteristic adaptations of people for network skills, beliefs, habits, and goals. These characteristics originated from parental modelling, cultural influences, or history of reinforcements. Therefore, every trait can express in cultural conditional ways and must understand through human action and experience. The behaviour in one situation of a person can differ from another. Some may tolerate uncertainty more than others (Costa \& McCrae, 1998). But personality traits are enduring dispositions, yet possible to change over a long period as a result of the universal maturation process, life experiences, and restorative interventions. Generally, personality explains about individuals, but culture explains societies. Individuals and culture connect as the bond between trees to the forest (Hofstede \& McCrae, 2004; Benedict, 1934) 
however, culture is treated as an internal logic of the person then the personality shapes the behaviour of the person (Hofstede \& McCrae, 2004; Yaprak, 2008). Thus, it can be argued that being a trait, PI may also have cultural influences on its' characteristics, which is necessary to study further.

\subsection{Importance of measuring cultural values at the Individual level.}

Culture consists of meanings, beliefs, practices, symbols, norms, values and shapes or justifies beliefs, actions, goals of an individual and groups (Schwartz, 2006). It plays a vital role in the consumer's decision making and creates different behaviours of the individual (Peter \& Olson, 2010; Henry, 1976). Learned beliefs or behavioural patterns cope with recurring experiences, passed from generation to generation, and shared by the set of people living in the society. It pervades a person's day-to-day activities and affects consumer behaviour (Henry, 1976; Spiers et al., 2014). Cultures which consider tradition as their terminal value, may be relatively slow in adoption and diffusion curves. But cultures with innovativeness will have much faster adoption cycles. For instance, some cultures heavily weigh some subjective norms like the household elder's opinion, while some cultures tend to emphasize other heroes, or on none at all.
Therefore, the weight of attitudinal and subjective norms may differ from one culture to another (Luna \& Gupta, 2001). Culture influences the behaviour of the individual through aspects of values, heroes, rituals, and symbols (Hofstede, 1997, as cited in Luna \& Gupta, 2001; Sun, 2008). Schwartz finds that most Asian countries have hierarchical and embedded cultures, which value social order, respect for tradition, security, obedience, wisdom, social power, authority, humility, and wealth.

In Sri Lanka, the identified main socio-cultural factors (such as family, caste, education, class, ethnicity, and religion) have distinctive structures and effects on individual behaviour (Gamage et al.,2003; Nanayakkara, 1985). It has high involvement in developing cultural patterns like dependence, lack of selfconfidence, lack of freedom, accepting the status quo, attitude towards work, respect for authority, loyalty, and collective human rights, that are critical to understanding (Gamage \& Wickramasinghe, 2012; Rajapakse, 2012). Compared to the Western countries, Sri Lankans prefer a more "structured" social order; therefore, they are less autonomous and more dependent on their surrounding social system (Gamage et al., 2003). According to Hofstede's dimensions, Sri Lanka is in the collectivism dimension (Score of 35 ); the values of the society 
have not built by the individual but by the family. Family orientation was measured by affection for family, interaction with family members, parental influence on thought, and tendency to compromise subjective needs with family needs (Tan \& Farley, 1987). For example, decision making within the family is usually made by the parents or spouse. It reduces opportunities for children to evaluate their judgments. They tend to seek advice and approval more frequently: and accepts the opinions of adults. It is a semifeudal belief that authority is positional and grows with wisdom and age (Nanayakkara,1985). Hofstede's national dimensions scorecard shows that Sri Lanka scored high in PD, which beliefs more on authority and hesitancy to argue. Further, people tend to evaluate the status of a person from the job they do. The lower social class person tends to depend on the levels above. Top positions are always instituted with power, wealth, and status. This discourages the development of self-confidence but motivates people to gain status and power by working.

The national culture of Sri Lanka is identified as collectivistic, PD and feminine, but not into UA and long-term orientation. But it is required to identify the individual cultural values towards the market. This is because, in the market, the consumer first acquires knowledge and then physically connects with innovations to gain a general understanding. Before choosing the product, he mentally connects the product with his present and future situations. This mental process is mainly influenced by, his cultural background (Rogers, 1971; Han \& Shavitt, 1994).

Most of the studies of cultural values compare nations that vary culturally. But that approach fails to stipulate how personal cultural values are related to marketing. National-level studies on culture standardize that all people within a nation have the same culture, regardless of individual differences in their cultural values. Therefore, to fill this gap, cultural values at the individual level need to be further measured (Yoo \& Donthu, 2002; Dobre, Dragomir \& Preda, 2009; McCoy, Galletta \& King, 2005) Cultural traits can be legitimized and shaped at the level of individual traits. Therefore, it is best to measure personal traits at a cultural level (Hofstede \& McCrae, 2004).

\section{THEORETICAL GAP}

Not all the individuals in the systems adopt a product at the same time (Rogers, 1971). Different individuals respond differently to the same situation, but if they share a common trait, their response is consistent in the same situation (Johnson,1997). According to the IDT, an individuals' IN is affected by the individual's characteristics, and 
by the nature of the social system (Rogers, 1971). Also, some researchers have studied how individuals' IN is affected by an individual's demographic characteristics (Park and Kim, 2010) and investigated how national cultural backgrounds of consumer innovativeness (CI) play cross-culturally (Benedict, 1934). Rogers (1971) has argued that socio-economic status, personality variables, and communication behaviour are identified characteristics of adopter categories that are influencing the decision process. He has not directly talked about the contribution from the culture or cultural values to the PI by considering it as a trait. Hirschman (1980) argues that although there is a lot of empirical research to discuss IN, its' origin has been kept obscure. The reason might be considering IN as a trait; so, it makes them think that an individual is born with the characteristics of IN. Also, over a period of time, all traits may tend to change relative to social and cultural implications.

There are few studies done by different researchers related to IN, still they have not discussed the implications of individual cultural values to the PI. For example, studies of Hirschman (1980) have segregated actual innovativeness to vicarious innovativeness (attainment of new information on new products) and adoptive innovativeness (attainment of new products). He has hinted that novelty-seeking and creativity influencing the PI. However, he also did not discuss cultural values in his studies.

Like some other examples given in Table 1, it was found that IN is a major area of many research studies. But it was realized that there is a dearth of knowledge on the implications of the internal cultural values of the person (ICV) towards PI. However, the involvement of national culture in innovation is captured in few studies.

Table 1: Existing knowledge on Innovativeness

\begin{tabular}{|c|c|}
\hline $\begin{array}{c}\text { Author and } \\
\text { Year }\end{array}$ & Area of the study \\
\hline $\begin{array}{l}\text { Ostlund } \\
(1974)\end{array}$ & $\begin{array}{l}\text { Predictors of IN } \\
\text { (Perceived innovation } \\
\text { attributes) }\end{array}$ \\
\hline $\begin{array}{l}\text { Midgley \& } \\
\text { Dowling } \\
(1978)\end{array}$ & $\begin{array}{l}\text { IN, Situation effect, } \\
\text { Communications }\end{array}$ \\
\hline $\begin{array}{l}\text { Hirschman } \\
\text { (1980) }\end{array}$ & $\begin{array}{l}\text { Novelty seeking, } \\
\text { Creativity on IN }\end{array}$ \\
\hline Lee (1990) & $\begin{array}{l}\text { Determinants of National } \\
\text { Innovativeness (NI) }\end{array}$ \\
\hline $\begin{array}{l}\text { Goldsmith } \\
\text { \& Hofacker } \\
(1991)\end{array}$ & Scale to measure IN \\
\hline $\begin{array}{l}\text { Deshpande } \\
\text { et al., (1993) }\end{array}$ & $\begin{array}{l}\text { Organizational } \\
\text { Innovativeness (OI), } \\
\text { Business performance }\end{array}$ \\
\hline $\begin{array}{l}\text { Lynn \& } \\
\text { Gelb (1996) }\end{array}$ & $\begin{array}{l}\text { Individualism, UA, } \\
\text { Purchasing power on } \\
\text { national level, new }\end{array}$ \\
\hline
\end{tabular}











Figure 2: Concept Map

Note: Concept Map explains the connection between the concepts, based on the recent evidence found in the literature to express the understanding of the researcher of the concepts relevant to this article (M. Kinchin \& B. Hay, 2000; Maxwell, 2012).

The boxes in Figure 1 represent the theories and illustrates the connection between concepts as discussed in the relevant theory itself. For example, according to the IDT, IN is a prior condition for the IDP. The arrows of the diagram show the connections between the concepts found in the literature and the dashed arrows are to visualise the objectives of the research and new areas to explore.

Objective 1: To examine the contribution of ICV to the concept of PI and discover the characteristics of ICVs associated with each PI category discussed in IDT.
Objective 2: To understand how ICV contribute to the IDP of different PI categories.

In further explaining the connections presented in Figure 1, many studies have described PI as a trait and traits inspired by the culture. Table 2 illustrates the latest findings on the same.

Table 2: Existing literature on

Personal Innovativeness and Traits

\begin{tabular}{|l|l|}
\hline & Author and the Year \\
\hline Pr as a & (Leavitt \& Walton \\
& 1975; Midgley \& \\
& Dowling, 1978; \\
& Hirschman,1980; \\
& Venkatraman,1991; \\
& Agarwal \& \\
& Prasad,1998; \\
& Roehrich, 2004; Lu et \\
& al.,2005; Dobre et al., \\
& 2009; Xu \& Gupta, \\
& 2009; Park \& Kim, \\
& 2010; Bouwman et \\
& al.,2014; Lu ,2014; \\
& Rahman et al.,2014; \\
& Thakur, Angriawan \& \\
\hline
\end{tabular}




\begin{tabular}{|l|l|}
\hline & $\begin{array}{l}\text { Summey,2016; } \\
\text { Truong et al.,2017; } \\
\text { Krey et al.,2019; } \\
\text { Klein,Horak, Li \& } \\
\text { Bacouel } \\
, 2019 ; \text { Esfahani \& } \\
\text { Reynolds ,2021) }\end{array}$ \\
\hline $\begin{array}{l}\text { Traits } \\
\text { influenced } \\
\text { by culture }\end{array}$ & $\begin{array}{l}\text { (McCrae \& Costa } \\
\text { Costa ,1998; Church } \\
\text { 2000; Hofstede \& } \\
\text { McCrae ,2004; } \\
\text { Fleeson \& } \\
\text { Jayawickreme ,2015) }\end{array}$ \\
\hline
\end{tabular}

Also, as stated in many definitions; culture influences society by its values (Deshpande et al.,1993; Yeniyurt \& Townsend, 2003; Kirkman et al.,2006; Geertz, 1973; Hofstede \& McCrae, 2004; Benedict, 1934; Yaprak, 2008; Gamage \& Wickramasinghe,2012; Maitland, 1999). So, it is important to study the value structure when understanding IN, its significance to the customer's cognitive structure, and personal values (Steenkamp et al., 1999). The values pretence on consumer motives, intention, and attitude of the person; also, it can be used to explain a culture or a subgroup (Henry, 1976; Sun, 2008; Schwartz, 2006; Daghfous et al.,1999).

As visualized in Table 3, there are published studies describing the relationship between values and IN in different phases. For example, they discuss OI, NI, and CI. Similar research done by Sun, Lee \& Law (2018) has shown the impact of cultural values (collectivism, long-term

orientation, and masculinity) on $\mathrm{TA}$ at the individual level. There, they measure national cultural values on an individual level. Also, Soares et al. (2007) make a similar point in their study, explaining how an individual behaves in individualistic/ collectivistic, UA, PD, and MF societies and how it results in innovativeness. In another aspect, Steenkamp et al., (1999) expound how customer IN is affected by national cultural values and has found consumers in individualistic and masculine countries are more innovative compared to the customers of UA. Similarly, Steenkamp et al., (1999) and Dobre et al., (2009) have explained the receptivity of a person to culture by discussing the cultural dimensions broadly in the national perspective. However, up to now far, too little attention has been given to understanding ICV (emerging from the inside) into PI but rather many of the studies have covered national cultural values into individual contexts or have conducted cross-cultural studies. 
Table 3: Existing literature on values to the innovativeness, diffusion, and technology acceptance

\begin{tabular}{|c|c|c|}
\hline & Values covered in the research & $\begin{array}{c}\text { Author and the } \\
\text { Year }\end{array}$ \\
\hline \multirow{6}{*}{ CI } & $\begin{array}{l}\text { Personal values (Sensation-seeking, } \\
\text { Pleasure and happiness in life, Warm } \\
\text { relationships, Self-respect, Respect by } \\
\text { others, Search for security, Sense of } \\
\text { belonging) }\end{array}$ & $\begin{array}{l}\text { Daghfous, Petrof } \\
\text { \& Pons (1999) }\end{array}$ \\
\hline & $\begin{array}{l}\text { Consumer values (Functional value, } \\
\text { Social value, Epistemic value, } \\
\text { Conditional value, Emotional value) }\end{array}$ & Hur et al., (2011) \\
\hline & $\begin{array}{l}\text { Social Values } \\
\text { (Being well respected, Security, Sense } \\
\text { of belonging, Excitement, Self- } \\
\text { respect, Sense of accomplishment, } \\
\text { Fun and enjoyment of life, Self- } \\
\text { fulfilment, Warm relationship) }\end{array}$ & $\begin{array}{l}\text { Goldsmith \& } \\
\text { Stith (1993) }\end{array}$ \\
\hline & $\begin{array}{l}\text { Social Values (Opinion leadership, } \\
\text { Status) }\end{array}$ & $\begin{array}{l}\text { Rahman et al. } \\
\text { (2014) }\end{array}$ \\
\hline & $\begin{array}{l}\text { Cultural Values to Cross-cultural } \\
\text { study }\end{array}$ & $\begin{array}{l}\text { Soares et al., } \\
(2007)\end{array}$ \\
\hline & $\begin{array}{l}\text { Personal Values (Resultant } \\
\text { conservation, Resultant self- } \\
\text { enhancement) } \\
\text { National Cultural Values }\end{array}$ & $\begin{array}{l}\text { Steenkamp et al. } \\
\text { (1999) }\end{array}$ \\
\hline IN & \multirow{2}{*}{ National Cultural Values } & $\begin{array}{l}\text { Dobre et al. } \\
(2009)\end{array}$ \\
\hline $\begin{array}{l}\text { Network } \\
\text { Diffusion }\end{array}$ & & Maitland (1999) \\
\hline
\end{tabular}




\begin{tabular}{|c|c|c|}
\hline NI & & $\begin{array}{l}\text { Lynn \& Gelb } \\
\text { (1996) } \\
\text { Guillén \& } \\
\text { Deckert (2021) }\end{array}$ \\
\hline $\begin{array}{l}\text { National } \\
\text { Diffusion }\end{array}$ & & $\begin{array}{l}\text { Yeniyurt \& } \\
\text { Townsend (2003) }\end{array}$ \\
\hline $\begin{array}{l}\text { TA at an } \\
\text { Individual level }\end{array}$ & & Sun et al. (2018) \\
\hline$\overline{\text { OI }}$ & $\begin{array}{l}\text { Individual Values (Power, } \\
\text { Achievement) }\end{array}$ & $\begin{array}{l}\text { Taştan \& } \\
\text { Davoudi, (2017) }\end{array}$ \\
\hline PI & $\begin{array}{l}\text { Functional and ergonomic Values } \\
\text { (Expected usefulness, Expected ease } \\
\text { of use) } \\
\text { Hedonic Values (Expected } \\
\text { enjoyments) } \\
\text { Symbolic Values (Expected visibility, } \\
\text { Expected self-expressiveness) }\end{array}$ & Krey et al. (2019) \\
\hline $\begin{array}{l}\text { Innate } \\
\text { innovativeness } \\
\text { and Fashion } \\
\text { innovativeness }\end{array}$ & $\begin{array}{l}\text { Personal Values (Personal self, } \\
\text { Ambition, Power) }\end{array}$ & $\begin{array}{l}\text { Lyu, Hahn \& } \\
\text { Sadachar (2018) }\end{array}$ \\
\hline IN & $\begin{array}{l}\text { Personal Values } \\
\text { (Stimulation, Self-direction, } \\
\text { Universalism, Benevolence, Tradition, } \\
\text { Conformity, Security, Power, } \\
\text { Achievement, Hedonism, Self- } \\
\text { enhancement, Conservation, Self- } \\
\text { transcendence, Openness to change) }\end{array}$ & $\begin{array}{l}\text { Potocan \& } \\
\text { Nedelko (2013) }\end{array}$ \\
\hline $\begin{array}{l}\text { Technological } \\
\text { innovativeness }\end{array}$ & Cultural Values (Cross cultural) & Klein et al. (2019) \\
\hline $\begin{array}{l}\text { Employee } \\
\text { Innovativeness }\end{array}$ & Organizational cultural values & $\begin{array}{l}\text { Hab'Imana \& } \\
\text { Ssempebwa } \\
(2020)\end{array}$ \\
\hline
\end{tabular}


The concepts presented in Hofstede's value dimensions have been used for many cultural and cross-cultural studies to understand national cultures (Hofstede \& Bond, 1984; Hooi, 2007; Mooij \& Hofstede, 2011; Mooij \& Hofstede, 2010; Hofstede, 1983; Sharma, 2010; Kassim \& Abdullah, 2010; Roth, 1995; Soares et al., 2007). The same dimensions were recommended to consider as individual values for understanding the behaviour of an individual (Donthu \& Yoo, 1998; Kirkman et al.,2006; Hofstede, 2011; Roth, 1995; Yoo et al., 2011; Gong et al., 2007; Han \& Shavitt, 1994; Sun et al., 2018; Hwang, 2005; Jung \& Kellaris, 2004; Hui \& Triandis, 1986; Daniels \& Greguras,2014). However, none of the above researchers has focused on understanding the impact of these concepts on IN as a value or as a characteristic of an individual. For example, it is required to understand how an individual with individualistic or collectivistic characteristics, follows up on their IN. Maybe the country or society is into the individualistic category, but a native could be a collectivistic person who believes in taking opinions from his family or friends before making a decision. In such scenarios, the IN of the person could result differently

regardless of the cultural value of the entire country. Although the concepts of IC, MF, PD, and UA are grouped together in
Hofstede's dimension, those concepts are not limited to Hofstede's value in dimension only. These concepts are theoretical concepts used by many researchers and theorists in their studies. For example, the Theory of Individualism and collectivism talks about individualism and collectivism; Social Distance Theory of Power talks about Power Distance; Feminist Theory talks about Masculinity and Femininity, and Theory of Uncertainty Identity discusses how people avoid uncertainty by understanding the uncertainty.

Some research explains the effect of IN is significant when individuals observe social identifications and cultural values (Hur, Yoo \& Chung, 2011). Identifying a relationship between social values on IN for a particular product does not prevent further exploration but require deep investigation on understanding its behaviour for a separate or new product category (Goldsmith \& Stithx,1993).

Overall, there is limited knowledge yet on how PI contributed by the individual's cultural values which might be generated by the origin of his family, groups, past experiences, and culture of the society. If one researcher identifies the motives behind the behaviour, another could recognise that the identified clarification is incomplete. Therefore, further studies are extremely required to find the 
origin of the traits and beliefs (Johnson,1997). Regardless of globalization and convergence of markets, consumers continue to reclaim their cultural identities, heritage, and ancestry. Because of the markets being driven by the customer's needs and those needs are purely based on cultural values, marketers must understand cultural implications on consumer behaviour when positioning the products (Yaprak, 2008; Aaker \& Maheshwaran, 1997; Liu, Furrer, \& Sudharshan,2001; Cakır \& Solak, 2015). Failing to consider the differences created by the culture might cause failure in the business (Spiers et al., 2014). Though technology solutions are utilized to coordinate, communicate, and achieve efficiencies, cultural differences of countries might impact the efficiency and effectiveness of IT deployment (Straub et al, 2002). In brief, culture is explained as the way of life of the people and certainly has implications for an individual's behaviour (Maitland, 1999). In light of this, many researchers have recommended examining culture and social influences (Shiraj, 2015; Alalwan et al.,2014; Alsajjan \& Dennis, 2010; AbuShanab et al., 2010).

As mentioned above, it is important to look at the contribution of ICV into PI. But the study does not end there. As mentioned in the IDT, PI is a key element for IDP. If so, the influences of ICV could extend to
IDP. In that case, if it is found that ICV inspires PI, then it should also look at how it inspires IDP. This requirement is captured by objective 2 described above. It is required to see how ICV inspires each stage of IDP to understand its contribution to the final decision of the customer. The study methodology required to meet these objectives is described below.

\section{METHODOLOGY}

This is a conceptual paper with an ongoing qualitative study, that would surface the hidden insights of the people and would understand the meanings of the individual by observing how that person's IN has influenced by his cultural values. This follows an inductive approach since it understands the meaning of humans' for using a product and it makes it less apprehensive to generalize the result (Saunders et al., 2009). The sample has been selected using the purposive sampling mechanism to capture all the PI categories (Innovators, early adopters, early majority, late majority, and laggards). The selected respondents were interviewed with semi-structured questions to meet objective 1 and 2. Responses will be analysed using thematic analysis to understand the themes and subthemes of the study. 


\section{CONCLUSION}

This article highlights a theoretical gap, that will be addressed by the research question and objectives. The results of the overall study will contribute to the theory, by providing an extension to the IDP and will explain IDP from a cultural perspective. In addition to the theoretical contribution, this research will benefit the industry under study for better decision making. Consumers think before they get to a facility. They would recognize service or product better that speaks to their culture (Takieddine \& Sun, 2015; Abessi \& Haghighy, 2011; Chau \& Lai, 2003). This research results will shed light on industrial specialists to get a better understanding of the areas where ICV becomes a reason for customers' negative or positive behaviour. For example, if adopting a product/service depends on risk analysis, which means people are more considerate of uncertainty avoidance (Hofstede,2011). Then the Industry specialists should focus on strengthening the security of the technology. In other words, if the research results show that Laggards are focused on collectivism; when designing promotional campaigns, industry specialists should remember that collectivists are "we conscious". Therefore, to motivate Laggards to get the product, they should focus more on team benefits (Hofstede,2011; Hofstede \&
McCrae, 2004). Likewise, this study expands the academic/industry knowledge about the cultural values of individuals according to their PI category. For instance, studying innovators and identifying their ICV will discern if those ICVs impacts for him to become an innovator. In doing so, the author effectively advocates product / service providers on the verge of new developments; Here, the focus is on the interventions needed to improve the client's PI or their past experience, knowledge, and their feasibility exceptions, etc.

\section{REFERENCES}

Aaker, J. \& Maheswaran, D. (1997). The Effect of Cultural Orientation on Persuasion. Journal of Consumer Research, 24(3), 315-328.

Abessi, M., \& Haghighy, T. (2011). Internet Banking Technology Acceptance Model: A Focus on Hofstede Cultural Dimensions. In International Conference on Management Science and e-Business Engineering. Retrieved from https://papers.ssrn.com/s ol3/ papers.cfm?abstract_id=1 $\underline{898715}$ 
Aboagye, E., Agbezuge, E., Antwi, H., Dagadu, J., \& Ansong, M. (2016). EBanking Preferences and Middle Class Values in Ghana. Journal of Computer Sciences and Applications, 4(2), 3546.doi: $10.12691 /$ jcsa-4$2-2$

Abubakre, M., Zhou, Y., \& Zhou, Z. (2020). The impact of information technology culture and personal innovativeness in information technology on digital entrepreneurship success. Information Technology \& People, ahead-of$\operatorname{print}($ ahead-of-print). doi: $\quad 10.1108 /$ itp-012020-0002

AbuShanab, E., Pearson, J., \& Setterstrom, A. (2010). Internet Banking and Customers' Acceptance in Jordan: The Unified Model's

Perspective. Communicat ions of the Association for Information Systems, 26, 493-524.

Agarwal, R., \& Prasad, J. (1998). A conceptual and operational definition of personal innovativeness in the domain of information technology. Information System Research, 9(2), 2042015.
Alalwan, A., Dwivedi, Y., \& Williams, M. (2014). Examining Factors Affecting Customer Intention and Adoption of Internet Banking In Jordan. In UK Academy for Information Systems Conference Proceedings. UK Academy for Information Systems.

Alsajjan, B., \& Dennis, C. (2010). Internet banking acceptance model: a cross-market examination. Journal of Business Research, 63.

Benedict, R. (1934). Patterns of Culture (pp. 46,251-255). Boston and New York: The riverside press

Bigné-Alcañiz, E., Ruiz-Mafé, C., Aldás-Manzano, J. \& Sanz-Blas, S. (2008). Influence of online shopping information dependency and innovativeness on internet shopping adoption. Online Information Review, 32(5), pp.648-667. doi: $10.1108 / 1468452081091$ 4025

Bouwman, M., Kommers, P., \& Deursen, A. (2014). Revising TAM for hedonic location-based social networks: the influence of TAM, perceived enjoyment, innovativeness and extraversion. Internation 
al Journal of Web Based

Communities, 10(2), 188.

doi:

$10.1504 / \mathrm{ijwbc} .2014 .0603$ 55

Cakır, R., \& Solak, E. (2015). Attitude of Turkish EFL Learners towards eLearning through Tam Model. Procedia - Social and Behavioural Sciences, 176, 596-601. doi:

$10.1016 /$ j.sbspro.2015.01 .515

Carl, D., Gupta, V., \& Javindan, M. (2004). Power distance. In R. House, P. Hanges, M. Javidan, P. Dorfman \& V. Gupta, Culture, Leadership, and Organizations: The GLOBE Study of 62 Societies. Sage Publications.

Chao, C., Reid, M., \& Mavondo, F. (2012). Consumer Innovativeness Influence on Really New Product Adoption. Australasian Marketing Journal, 20(3), 211-217. https://doi.org/10.1016/j. ausmj.2012.02.001

Chau, P., \& Lai, V. (2003). An Empirical Investigation of the Determinants of User Acceptance of Internet Banking. Journal of Organizational Computing and Electronic
Commerce, 13(2), 123145.

Church, T. (2000). Culture and personality: Toward an integrated cultural trait psychology. Journal of Personality, 64(4).doi:10. 1111/1467-6494.00112

Daghfous, N., Petrof, J., \& Pons, F. (1999). Values and adoption of innovations: a cross-cultural study. Journal of Consumer

Marketing, 16(4), $314-$ 331.doi: $10.1108 / 0736376991027$ 7102

Daniels, M., \& Greguras, G. (2014). Exploring the Nature of Power Distance. Journal of Management, 40(5), 1202-1229. doi: $10.1177 / 0149206314527$ 131

Deshpande, R., Farley, J., \& Webster, F. (1993). Corporate Culture, Customer Orientation, and Innovativeness in Japanese Firms: A Quadrad Analysis. Journal of Marketing, 57(1), 23.doi: $10.2307 / 1252055$

Dobre, C., Dragomir, A., \& Preda, G. (2009). Consumer innovativeness: a marketing approach. Management 
\& Marketing, 4(2), 1934.

Donthu, N. \& Yoo, B. (1998). Cultural Influences on Service Quality Expectations. Journal of Service Research, 1(2), 178-186.Hofsted, G. (1983). The Cultural Relativity of Organizational Practices and Theories. Journal of International Business Studies, 14(2), 75-89.doi: $10.1177 / 1094670598001$ 00207

Emrich C., Denmark, F. \& Hartog, D. (2004). CrossCultural differences in Gender Egalitarianism. In R. House, P. Hanges, M. Javidan, P. Dorfman \& V. Gupta, Culture, Leadership, and Organizations: The GLOBE Study of 62 Societies. Sage Publications.

Fleeson, W., \& Jayawickreme, E. (2015). Whole Trait Theory. Journal of Research in Personality, 56, 82-92. Retrieved from https://www.ncbi.nlm.nih .gov/pmc/articles/PMC44 $72377 /$

Gamage, H. \& Wickramasinghe, A. (2012). Culture of social in situations and behavioural manifestations in entrepreneurship development.

Interdisciplinary journal of contemporary research in business, 4(7), 64-79.

Gamage, H., Cameron, D., \& Woods, E. (2003). Are Sri Lankan Entrepreneurs Motivated by the Need for Achievement?. In International Conference on Sri Lanka Studies. Matara, Sri Lanka.

Garcia, R., \& Calantone, R. (2002). A critical look at technological innovation typology and innovativeness terminology: a literature review. Journal of Product Innovation Management, 19(2), 110132.doi: 10.1111/15405885.1920110

Geertz, C. (1973). The interpretation of cultures. NEW YORK: Basic Books, Inc.

Goldsmith, R., \& Hofacker, C. (1991). Measuring consumer innovativeness. Journal of The Academy of Marketing

Science, 19(3), 209221.doi: 10.1007/BF02726497

Goldsmith, R., \& Stith, M. (1993). The social values of fashion innovators. Journal of Applied Business 
Research, 9(1), $\quad 10-$ 16.doi: 10.19030/jabr.v9i1.6089

Gong, W., Li, Z., \& Stump, R. (2007). Global internet use and access: cultural considerations. Asia Pacific Journal of Marketing and Logistics, 19(1), 57-74. doi: $10.1108 / 1355585071072$ 0902 .

Guillén, V., \& Deckert, C. (2021). Cultural influence on innovativeness - links between "The Culture Map" and the "Global Innovation Index". International Journal of Corporate Social

Responsibility, 6(1). https://doi.org/10.1186/s4 0991-021-00061-x

Hab'Imana, J., \& Ssempebwa, J. (2020). A Conceptual Paper on Innovativeness of Academic Staff. Journal of Education and Practice, 11(18). doi: 10.7176/jep/11-18-06

Han, S. and Shavitt, S. (1994). Persuasion and Culture: Advertising Appeals in Individualistic and Collectivistic Societies. Journal of Experimental Social Psychology, 30(4), pp.326-350.doi: 10.1006/jesp.1994.1016
Henry, W. (1976). Cultural Values Do Correlate with Consumer Behavior. Journal of Marketing Research, 13, 121127.doi: $10.1177 / 0022243776013$ 00201

Hirschman, E. (1980). Innovativeness, Novelty Seeking, and Consumer Creativity. Journal of Consumer

Research, 7(3), 283295.doi: 10.1086/208816

Hofstede 2011 Dimensionalizing Cultures: The Hofstede Model in Context

Hofstede, G. \& Bond, M. (1984). Hofstede's Culture Dimensions: An Independent Validation Using Rokeach's Value Survey. Journal of Cross-Cultural

Psychology, 15(4), 417433.doi: $10.1177 / 0022002184015$ 004003

Hofstede, G. (1983). The cultural relativity of Organizational practices and theories. Journal of International Business Studies, 14(2), 75-89.doi: /10.1057/palgrave.jibs.84 90867

Hofstede, G., \& McCrae, R. (2004). Personality and Culture Revisited: Linking Traits and Dimensions of Culture. 
Cross-Cultural Research, 38(1), 52-88.doi: $/ 10.1177 / 1069397103259$ 443

Hooi, G. (2007). The Effects of Culture on International Banking Disclosures. Asia-Pacific Journal of Accounting \& Economics, 14, 7-25.doi: 10.1080/16081625.2007. 9720785

Hui, C., \& Triandis, H. (1986). Individualism-

Collectivism: A Study of Cross-Cultural

Researchers. Journal of Cross-Cultural

Psychology, 17(2), 225248. doi: $10.1177 / 0022002186017$ 002006

Hur, W., Yoo, J., \& Chung, T. (2011). The consumption values and consumer innovativeness on convergence products. Industrial Management \& Data Systems, 112(5), $\quad$ 688706.doi: $10.1108 / 0263557121123$ 2271

Hwang, Y. (2005). An Empirical Study of Online Trust and Consumer Behavior: Cultural Orientation, Social Norms, and Personal Innovativeness in Information Technology. In International Conference on
Information System. ICIS $2005 \quad$ Proceeding. Retrieved from https://aisel.aisnet.org/ici s2005/69

Jacques, P., Garger, J., Brown, C., \& Deale, C. (2009). Personality and Virtual Reality Team Candidates: The Roles of Personality Traits, Technology Anxiety and Trust as Predictors of Perceptions of Virtual Reality Teams. Journal of Business and Management, 15(2), 143157.

Johnson, J. (1997). Units of analysis for the description and explanation of personality. Academic Press.

Jung, J., \& Kellaris, J. (2004). Cross-national differences in proneness to scarcity effects: The moderating roles of familiarity, uncertainty avoidance, and need for cognitive

closure. Psychology and Marketing, 21(9), 739$753 . \quad$ doi: 10.1002/mar.20027

Kassim, N., \& Abdullah, N. (2010). The effect of perceived service quality dimensions on customer satisfaction, trust, and loyalty in e-commerce settings A cross cultural 
analysis. Asia Pacific

Journal of Marketing and

Logistics, 22(3), 351-

371.doi:

$10.1108 / 1355585101106$ 2269

Kirkman, B., Lowe, K., \& Gibson, C. (2006). A quarter century of Culture's Consequences: a review of empirical research incorporating Hofstede's cultural values

framework. Journal of International Business Studies, (37), 285320.doi:

10.1057/palgrave.jibs. 84 00202

Klein, A., Horak, S., Li, X., \& Bacouel Jentjens, S. (2019). Does culture frame technological innovativeness? A study of millennials in triad countries. European J. Of International

Management, 1(1), 1 . https://doi.org/10.1504/ej im.2019.10016816

Kluckhohn, F., \& Strodtbeck, F. (1961). Variations in value orientations. Evanston, Ill: Row, Peterson.

Krey, N., Chuah, S., Ramayah, T., \& Rauschnabel, P. (2019). How functional and emotional ads drive smartwatch adoption. Internet Research. doi:
10.1108/IntR-12-20170534

Leavitt, C., \& Walton, J. (1975). Development of a Scale for Innovativeness. Advances in

Consumer

Research, 2, 545-554.

Lee, C. (1990). Determinants of National Innovativeness and International Market Segmentation. Internatio nal Marketing Review, 7(5).

Liu, B., Furrer, O., \& Sudharshan, D. (2001). The Relationships between culture and behavioural intentions Toward Services. Journal of Service Research, 4(2), 118-129.doi: $10.1177 / 1094670501420$ 04

Lu, J. (2014). Are personal innovativeness and social influence critical to continue with mobile commerce?. Internet

Research, 24(2), 134159.

Lu, J., Yao, J., \& Yu, C. (2005). Personal Innovativeness, Social influences, and adoption of wireless internet services via mobile technology. Journal of Strategic Information Systems, 14, 245-268.doi: 10.1016/j.jsis.2005.07.00 3 
Luna, D. \& Gupta, S. (2001). An integrative framework for cross-cultural consumer behaviour. International Marketing Review, 18(1), 45-69.doi: $10.1108 / 0265133011038$ 1998

Luque M., \& Javindan, M. (2004). Uncertainty avoidance. In R. House, P. Hanges, M. Javidan, P. Dorfman \& V. Gupta, Culture, Leadership, and Organizations: The GLOBE Study of 62 Societies. Sage Publications.

Lynn, M., \& Gelb, B. (1996). Identifying innovative national markets for technical consumer goods. International Marketing Review, 13(6), 43-57.doi: $10.1108 / 0265133961015$ 1917

Lyu, J., Hahn, K., \& Sadachar, A. (2018). Understanding millennial consumer's adoption of 3D printed fashion products by exploring personal values and innovativeness. Fashion and Textiles, 5(1). doi: 10.1186/s40691-0170119-8

M. Kinchin, I., \& B. Hay, D. (2000). How a qualitative approach to concept map analysis can be used to aid learning by

illustrating patterns of conceptual

development. Educationa l Research, 42(1), 43-57.

Maitland, C. (1999). Global diffusion of interactive networks: The impact of culture. $A I$ \& Society, 13(4), 341-356.

Markus, H., \& Kitayama, S. (1991). Culture and the self: Implications for cognition, emotion, and motivation. Psychologica l Review, 98(2), 224-253. doi: $\quad 10.1037 / 0033$ 295x.98.2.224

Maxwell, J. (2012). Qualitative research design: An Interactive Approach (3rd ed.). Sage.

McCoy, S., Galletta, D., \& King, W. (2005). Integrating National Culture into IS Research: The Need for Current Individual Level Measures. Communicatio ns of the Association for Information Systems, 15. doi:

10.17705/1cais.01512

McCrae, R., \& Costa, P. (1997). Personality trait structure as a human universal. American Psychologist, 52(5), 509-516.doi: $10.1037 / / 0003-$ 066X.52.5.509

McCrae, R., \& Costa, P. (1998). Trait theories of 
personality. Advance Personality, 103-118.

Midgley, D., \& Dowling, G. (1978). Innovativeness: The Concept and Its Measurement. Journal of Consumer Research, 4, 229-242.doi: $10.1086 / 208701$

Mooij, M. \& Hofstede, G. (2010). The Hofstede model Applications to global branding and advertising strategy and research. International Journal of Advertising, 29(1), 85110.doi: $10.2501 / \mathrm{S} 026504870920$ $104 \mathrm{X}$

Mooij, M. \& Hofstede, G. (2011). Cross-Cultural Consumer Behaviour: A Review of Research Findings. Journal of International Consumer Marketing, 23, 181-192.doi: 10.1080/08961530.2011. 578057

Nanayakkara, G. (1985). Culture and management in Sri Lanka. Colombo

Orr, L., \& Hauser, W. (2008). A re-inquiry of Hofstede's Cultural Dimensions: A call for 21st Century Cross-Cultural research. The Marketing Management Journal, 18(2), 1-19.

Ostlund, L. (1974). Perceived Innovation Attributes as
Predictors of Innovativeness. Journal of Consumer Research, 1(2), 23.doi: $10.1086 / 208587$

Park, J., \& Kim, H. (2010). Impacts of Individual Innovativeness on the Acceptance of IT-based Innovations in Health Care Fields. Healthcare Informatics Research, 16(4), 290-298.doi: 10.4258/hir.2010.16.4.29 0

Peter, J. \& Olson, J. (2010). Consumer behaviour \& marketing strategy (9th ed.). New York: McGraw-Hill

Companies, Inc.

Phong Nguyen, N. (2020). The effects of crossfunctional coordination and competition on knowledge sharing and organisational innovativeness: A qualitative study in a transition economy. Journal of Intelligence Studies in Business, 1(1). doi:

10.37380/jisib.v1i1.561

Potocan, V., \& Nedelko, Z. (2013). Innovativeness of IT Managers - Exploring Influences of Personal Values on IT Managers' Innovativeness. Procedia Technology, 9, 291-303. doi: 10.1016/j.protcy.2013.12 
.033

Rahman, S., Saleem, S., Akhtar, S., Ali, T., and Khan, M. (2014). Consumers' Adoption of Apparel Fashion: The Role of Innovativeness, Involvement, and Social Values. International Journal of Marketing Studies, 6(3).doi: 10.5539/ijms.v6n3p49

Rajapakse, J. (2012). Can ERP adoptions change organisational culture in developing countries in Asia? An empirical investigation. In 45th Hawaii International Conference on System Sciences (pp. 50935101).doi: 10.1109/HICSS.2012.14 4

Roehrich, G. (2004). Consumer innovativeness Concepts and

measurements. Journal of Business Research, 57, 671-

677.doi:10.1016/S01482963(02)00311-9

Rogers, E. (1971). Diffusion of innovations (3rd ed.). London: Macmillan Publishing Co., Inc.

Roth, M. (1995). The Effects of Culture and Socioeconomics on the Performance of Global Brand Image Strategies. Journal of Marketing
Research, 32(2), 163175.doi:

$10.2307 / 3152045$

Saunders, M., Lewis, P., \& Thornhill,A.(2009). Rese arch Methods for Business Students (5th ed.). Pearson Education Limited.

Schwartz, S. (1999). A Theory of Cultural Values and Some Implications for Work. Applied Psychology, 48(1), 23-47. doi: $\quad 10.1111 / j .1464-$ 0597.1999.tb00047.x

Schwartz, S. (2006). A Theory of Cultural Value Orientations: Explication and Applications. Comparative Sociology, 5(2-3), 137-182.doi: $10.1163 / 1569133067786$ 67357

Seyed Esfahani, M., \& Reynolds, N. (2021). Impact of consumer innovativeness on really new product adoption. Marketing Intelligence \& Planning, ahead-of-print(ahead-ofprint). doi: $10.1108 / \mathrm{mip}-$ 07-2020-0304

Sharma, P. (2010). Measuring personal cultural orientations: Scale development and validation. Journal of The Academy of Marketing Science, 38(6), 787-806.doi: 
10.1007/s11747-0090184-7

Shiraj, M. (2015). Factors Influencing the Adoption of Internet Banking: (Special Reference to the South Eastern Region, Sri Lanka). In Second International Symposium. South Eastern University of Sri Lanka.

Smith, P., Dugan, S., \& Trompenaars, F. (1996). National Culture and the Values of Organizational Employees. Journal of Cross-Cultural Psychology, 27(2), 231$264 . \quad$ doi: $10.1177 / 0022022196272$ 006

Soares, A., Farhangmehr, M., \& Shoham, A. (2007). Hofstede's dimensions of culture in international marketing studies. Journal of Business Research, 60, 277284.doi:

10.1016/j.jbusres.2006.1 0.018

Spiers, S., Singh, M., \& Gundala, R. (2014). Culture and Consumer Behaviour-A Study of Trinidad \& Tobago and Jamaica. International Journal of Marketing Studies, 6(4), 92-99.doi: 10.5539/ijms.v6n4p92

Sri Lanka* - Hofstede Insights. (2020). Retrieved 21
April 2020, from https://www.hofstedeinsights.com/country/srilanka/

Steenkamp, J., Hofstede, F., \& Wedel, M. (1999). A Cross-National Investigation into the Individual and National Cultural Antecedents of Consumer Innovativeness. Journal of Marketing, 63(2), 55.doi: 10.2307/1251945

Straub, D., Loch, K., Evaristo, R., Karahanna, E., \& Strite, M. (2002). Toward a theory-based measurement of culture. Journal of Global Information

Management, 10(1).doi: 10.4018/jgim.200201010 2

Sun, S. (2008). Organizational Culture and Its Themes. International Journal of Business And Management, 3(12), 137141.doi: 10.5539/ijbm.v3n12p137

Takieddine, S. and Sun, J. (2015). Internet banking diffusion: A countrylevel analysis. Electronic Commerce Research and Applications, 14, pp.361371.doi: 10.1016/j.elerap.2015.06. 001

Tan, C. \& Farley, J. (1987). The Impact of Cultural 
Patterns on Cognition and Intention in Singapore. Journal of Consumer Research, 13, 540-544.doi: $10.1086 / 209087$

Taştan, S., \& Davoudi, S. (2017). The relationship between organizational climate and organizational innovativeness: testing the moderating effect of individual values of power and achievement. Internation al Journal of Business Innovation and Research, 12(4), 465 483.doi:

10.1504/IJBIR.2017.100 03335

Thakur, R., Angriawan, A., \& Summey, J. (2016). Technological opinion leadership: The role of personal innovativeness, gadget love, and technological innovativeness. Journal of Business Research, 69(8), 2764$2773 . \quad$ doi: 10.1016/j.jbusres.2015.1 1.012

Triandis, H. (2001). Individualism and collectivism: Past, present, and future. The Handbook of Culture and Psychology, 35-50.

Truong, Y., Klink, R., Simmons, G., Grinstein, A., \& Palmer, M. (2017).
Branding strategies for high-technology

products: The effects of consumer and product innovativeness. Journal of Business Research, 70, 85-91. doi: 10.1016/j.jbusres.2016.0 7.003

Turan, A., Tunç, A., \& Zehir, C. (2015). A Theoretical Model Proposal: Personal Innovativeness and User Involvement as Antecedents of Unified Theory of Acceptance and Use of Technology. Procedia Social and Behavioral Sciences, 210, 43-51. doi: 10.1016/j.sbspro.2015.11 .327

Venkatesh, V., Morris, M., Davis, G., \& Davis, F. (2003). User Acceptance of Information Technology: Toward a Unified View. MIS Quarterly, 27(3). doi: $10.2307 / 30036540$

Venkatraman, M. (1991). The impact of innovativeness and innovation type on adoption. Journal of Retailing, 67(1), pp.5167.

Waarts, E., \& Van Everdingen, Y. (2003). The Effect of National Culture on the Adoption of Innovations. Marketing Letters, 14(3), 217-232. 
Wu, M. (2006). Hofstede's Cultural Dimensions 30 Years Later: A Study of Taiwan and the United States. Intercultural Communication Studies.

Xu, H., \& Gupta, S. (2009). The effects of privacy concerns and personal innovativeness on potential and experienced customers' adoption of location-based services. Electronic Markets, 19(2-3), 137$149 . \quad$ doi: 10.1007/s12525-0090012-4

Yaprak, A. (2008). Culture study in international marketing: a critical review and suggestions for future research. International Marketing Review, 25(2), 215229.doi: $10.1108 / 0265133081086$ 6290

Yeniyurt, S., \& Townsend, J. (2003). Does culture explain acceptance of new products in a country?. International Marketing Review, 20(4), 377-396.doi: $10.1108 / 0265133031048$ 5153

Yi, M., Jackson, J., Park, J., \& Probst, J. (2006). Understanding information technology acceptance by individual professionals: Toward an integrative

view. Information \& Management, 43(3), 350$363 . \quad$ doi: 10.1016/j.im.2005.08.00 6

Yoo, B., and Donthu, N. (2002). The Effects of Marketing Education and Individual Cultural Values on Marketing Ethics of Students. Journal of Marketing Education, 24(2), 92-103.doi: $10.1177 / 0273475302242$ 002

Yoo, B., Donthu, N., \& Lenartowicz, T. (2011). Measuring Hofstede's Five Dimensions of Cultural Values at the Individual Level: Development and Validation of CVSCALE. Journal of International Consumer Marketing, 23(3), 193210.doi: 10.1080/08961530.2011. 578059 